\title{
MPPT ALGORITHMS USED IN PHOTOVOLTAICS
}

\begin{abstract}
Due to volatility of current-voltage characteristics of the photovoltaic module, MPPT algorithms are important element of photovoltaic power station. In most cases, MPPT algorithm controls power electronics converter, which receives power directly from one or more modules. Maximum power point changes its location together with insolation level temperature changes. There are also indirect, direct and artificial intelligence supported methods. Indirect methods are fractional methods and look-up table. Direct methods are Perturb \& Observe and Incremental conductance. Direct algorithms are widely used, because of their ability to model maximum power point significantly better than indirect methods. Artificial intelligence supported methods obtain even better results in determining optimal operating conditions. Usage of these algorithms allows to increase the efficiency of energy production, and furthermore financial benefits. Investment payback time can also be shortened by using these methods, which are still being improved.
\end{abstract}

Keywords: MPPT, photovoltaics, perturb and observe, incremental conductance, direct algorithms, indirect algorithms.

\section{Introduction}

In order to increase effectiveness of energy production by photovoltaic cells, it is necessary to use MPPT algorithm (Maximum Power Point Tracking). Such algorithm controls the converter which receives power directly from module or modules, which generate electrical power from solar power.

\subsection{Photovoltaic module current-voltage characteristic}

Characteristic points of the module, short circuit current $I_{S C}$ and open circuit voltage $U_{O C}$ depends respectively on insolation and module temperature.

\footnotetext{
${ }^{1}$ Piotr Hadaj, Department of Power Electronics, Power Engineering and Complex Systems, Rzeszów University of Technology, ul. Wincentego Pola 2, 35-959 Rzeszów, 178651772, e-mail: piotr.hadaj@prz.edu.pl

${ }^{2}$ Corresponding author: Marek Nowak, Department of Power Electronics, Power Engineering and Complex Systems, Rzeszów University of Technology, ul. Wincentego Pola 2, 35-959 Rzeszów, 178651772, e-mail: mnowak@prz.edu.pl
} 
Because these parameters can change dynamically in time, module characteristic changes too. As a result of changes of these variables, maximum power point changes its location. Different insolation levels cause short circuit current change, the higher insolation level, the higher short circuit current. Respectively, the lower insolation level, the lower short circuit current. Fluctuations of this parameter value does not affect open circuit voltage greatly. All characteristic was done in PSIM software. PSIM uses described equations (1)-(6), in order to model photovoltaic cell characteristics.

$$
\begin{aligned}
& i=i_{p h}-i_{d}-i_{r} \\
& i_{p h}=I_{s c 0} \cdot \frac{S}{S_{0}}+C_{t} \cdot\left(T-T_{r e f}\right) \\
& i_{0}=I_{0} \cdot\left(e^{\frac{q V d}{A k T}}-1\right) \\
& I_{0}=I_{s 0} \cdot\left(\frac{T}{T_{r e f}}\right)^{3} \cdot e^{\frac{q E g}{A k} \cdot\left(\frac{1}{T_{r e f}}-\frac{1}{T}\right)} \\
& i_{r}=\frac{V_{0}}{R_{s h}} \\
& T=T_{a}+k_{s} \cdot S
\end{aligned}
$$

In described equations $S$ stands for light intensity, and $S_{0}$ stands for light intensity under standard test conditions, which is normally $1000 \mathrm{~W} / \mathrm{m}^{2} . \mathrm{T}_{\text {ref }}$ is reference temperature and $R_{s}$ stands for series resistance of each solar cell in Ohm. $R_{s h}$ is shunt resistance of each cell. $I_{s c 0}$ stands for short circuit current of each solar cell at the reference temperature $T_{r e f}$ in A. $I_{s 0}$ is diode saturation current of each cell. Band energy of each cell is described as $E_{g}$. For each cell ideality factor A is needed, which is also called emission coefficient, which is around 2 for crystalline silicon or less for amorphous silicon. Temperature coefficient is $C_{t} . K_{s}$ defines how the light intensity affects the solar cell temperature. Value $q$ is the electron charge $\left(q=1.6 \cdot 10^{-19}\right), k$ is the Boltzmann constant, $T_{a}$ is the ambient temperature input and $V$ is the terminal voltage across the solar module. The current flowing out of the positive terminal of the module is defined as $i$.

Fig. 1. illustrates the dependence of current-voltage characteristic of the photovoltaic module of the insolation level changes, made created with PSIM. 


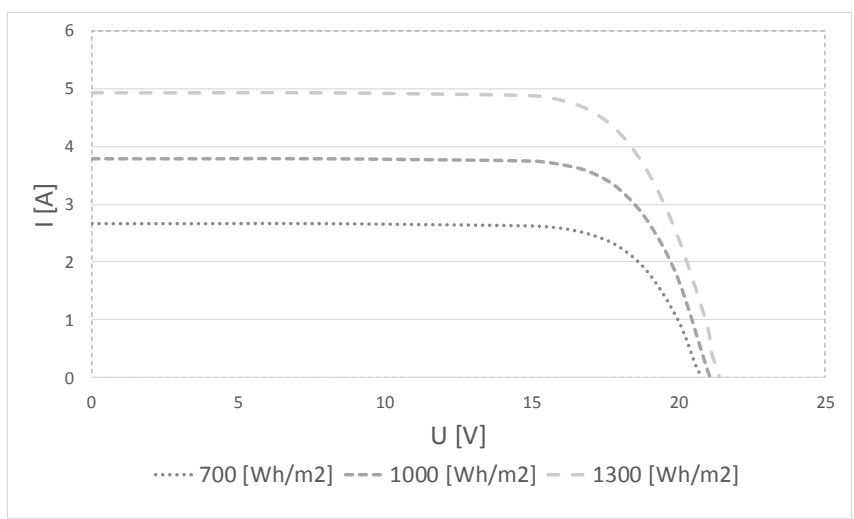

Fig. 1. The dependence of current-voltage characteristic of the photovoltaic module on the insolation level changes. Created with PSIM software.

Open circuit voltage varies with module temperature. Higher temperature causes lower open circuit voltage, and respectively, for lower temperatures the voltage will be higher. Therefore it is important to cool cells duly. In summertime, when insolation level is high, amount of produced electrical energy might be reduced by module heating. Fluctuations of this parameter value does not affect short circuit current greatly. Fig. 2 presents the dependence of open circuit voltage on the temperature of photovoltaic cells. Fig. 3 shows short circuit current change during temperature fluctuations.

Because the shape of module characteristic changed substantially, maximum power point (MPP - Maximum Power Point) changed its location. These changes are illustrated in Fig. 4 (dependence of the MPP on the insolation level) and Fig. 5 (dependence of the MPP on the module temperature).

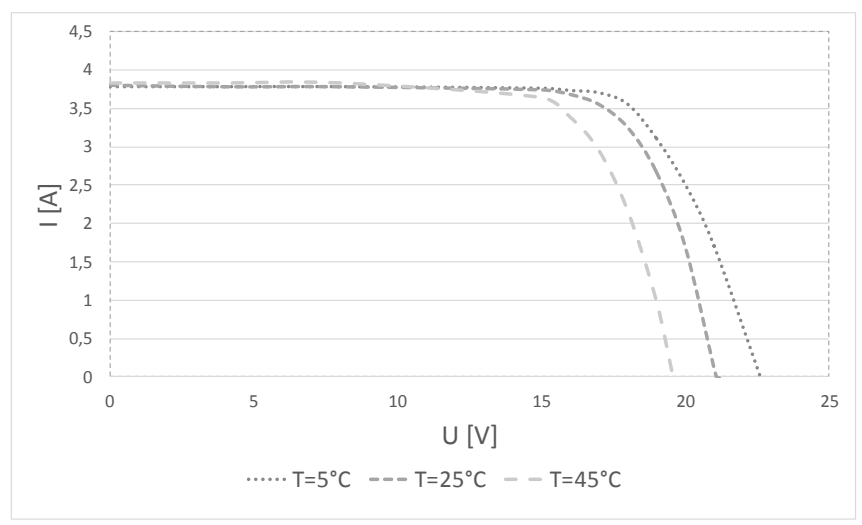

Fig. 2. The dependence on current-voltage characteristic of the photovoltaic module on the temperature of cells. Created with PSIM software. 


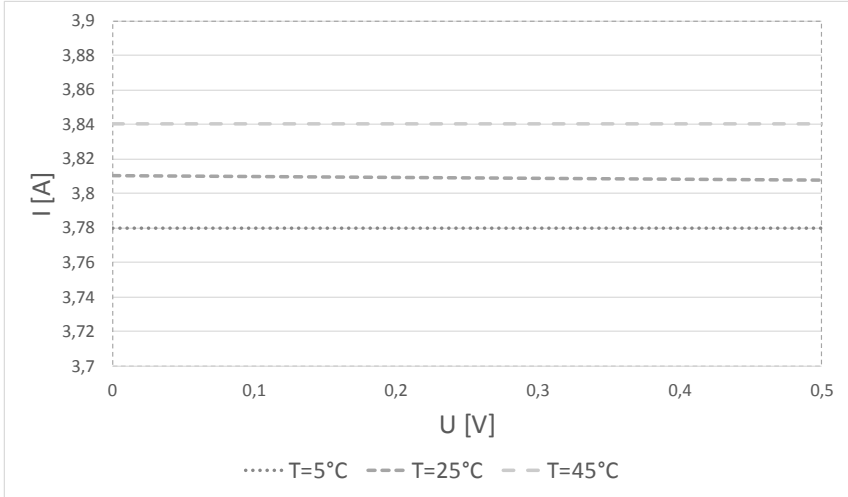

Fig. 3. Short circuit current dependence against temperature . Created with PSIM software.

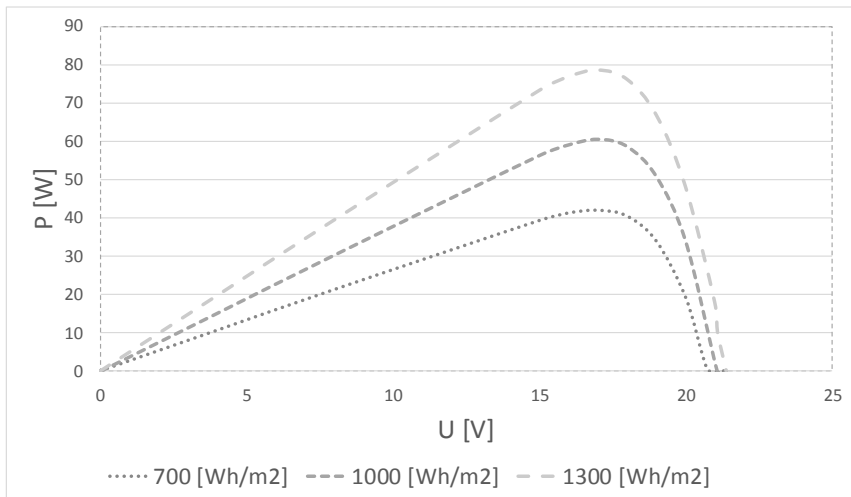

Fig. 4. Dependence of the MPP location on the varying insolation level. Created with PSIM software.

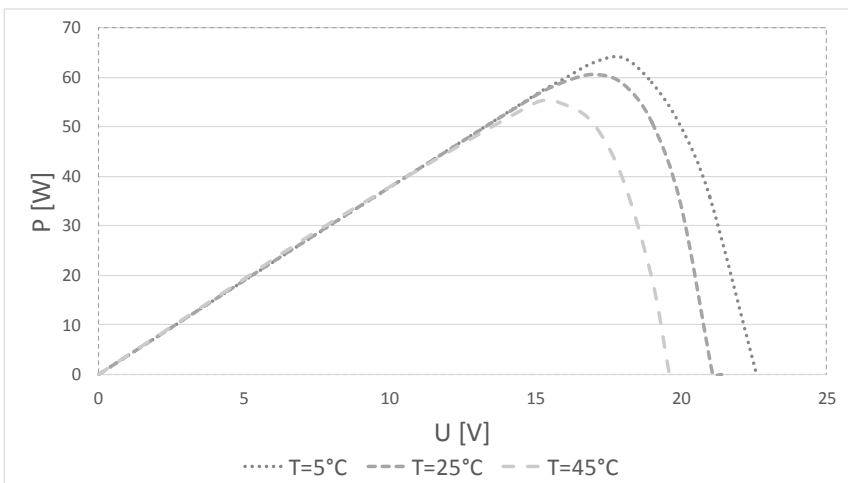

Fig. 5. Dependence of the MPP location on the varying module temperature. Created with PSIM software. 
In order to keep this operating optimally, these changes should be tracked in real time and reacted to respectively by changing the voltage or referential current on converter which runs MPPT algorithm. There are several methods of searching for optimal operating point of PV system.

\section{The division of MPPT algorithms}

MPPT algorithms divide usually in indirect methods, direct methods and based on artificial intelligence. Indirect algorithms are based on databases which may contain, for example, work characteristics for many different atmospheric conditions in which a module can generate energy. Controller takes this data and compares it to the actual state and choses best characteristic and uses it to set voltage or referential current. Direct methods base on measurements of voltage and current on converter that take place in real time. Using this information, it can determine power level received from the modules. Generally, these types of algorithms bring some oscillations to referential value, because the direction of current and voltage change is calculated in real time. There are some methods that use artificial intelligence. Generally, these methods are similar to conventional MPPT algorithms, but they are supported by neural networks and fuzzy logic techniques. By using these solutions, these methods can gain better maximum power point mapping which significantly increases system efficiency. $[1,2]$

\section{Indirect algorithms}

\subsection{Fractional methods}

These algorithms use approximated dependence between short circuit current, open circuit voltage and their values in maximum power point. From time to time, depending on which parameter is measured, module is shorted $\left(I_{S C}\right.$ measured) or opened ( $U_{O C}$ measured).

The main principle of open circuit voltage fraction method is to adopt approximated condition, that maximum power point voltage $\left(U_{M P P}\right)$ to open circuit voltage $\left(U_{O C}\right)$ ratio is constant (7).

$$
k_{U} \cong \frac{U_{M P P}}{U_{O C}}=\text { const }
$$


where: $k_{U}$ - voltage ratio,

$U_{M P P}-$ maximum power point voltage

$U_{O C}-$ open circuit voltage.

The ratio value depends on material and technology used to make photovoltaic cell. In this method, control process is based on temporary disconnecting the module and measuring open circuit voltage. Obtained value is multiplied by $k_{U}$ factor from formula (7), which gives the referential voltage which is also $U_{M P P}$ voltage (8).

$$
U_{R E F}=U_{M P P} \cong k_{U} U_{O C}
$$

where: $U_{R E F}-$ converter referential voltage.

Fraction of short circuit current method bases on approximated dependence, that maximum power point current $\left(I_{M P P}\right)$ to $I_{S C}$ ration is constant (9).

$$
k_{I} \cong \frac{I_{M P P}}{I_{S C}}=\text { const }
$$

where: $k_{I}-$ current ratio,

$I_{M P P}-$ maximum power point current

$I_{S C}-$ short circuit current.

Aforementioned ratio depends on material and technology used to make specific cell. In this method, control process is based on temporary shorting the module and current measurement. Obtained value is multiplied by current ratio, which gives the referential voltage to be used by converter. (10)

$$
I_{R E F}=I_{M P P} \cong k_{I} I_{S C}
$$

where: $\mathrm{I}_{R E F}-$ converter referential current.

Undoubted advantage of fractional methods is their simplicity - only one value has to be measured, possibility of use converter itself to make measurements and ease of implementation. Unfortunately, during measurements power is not supplied to the receiver, which undeniably lowers whole system efficiency. Also the dynamically changing module characteristic is problematical. There are some solutions, where one of modules is shorted or opened permanently. Then, controller can react to parameter changes (temperature, insolation) in real time, but operating conditions of permanently shorted or opened module can be significantly different from those supplying 
real receivers. In such situation maximal power point location may be inaccurate. Therefore, fractional methods are rarely used as independent MPPT algorithms, but they are often used to estimate optimal operating conditions in other widely used methods to shorten the time of reaching maximal power.

\subsection{Curve fitting method}

This method bases on approximation of photovoltaic module power characteristic using mathematical function, for example third-degree polynomial (11).

$$
P=a U^{3}+b U^{2}+c U+d
$$

On this basis function extreme point is calculated - maximum power point voltage (12).

$$
V_{M P P}=\frac{-b \pm \sqrt{b^{2}-3 a c}}{3 a}
$$

However, this method is somewhat problematic, because of calculation high complexity. Every parameter of the formula needs to be estimated depending on the atmospheric conditions, technology used in the production process and material, which cell is made of. Significant amount of resources are used to estimate optimal operating conditions. [1].

\section{3. "Look-up table" method}

This method uses a database consisting data about current and voltage values at the maximum power point for various atmospheric conditions. Algorithm used in this method gets needed values from memory and controls the converter basing on actual calculations. Such approach requires the use of large amounts of resources to build the database. It is also hard to predict all possible combinations of insolation and temperature levels. Furthermore, cell parameters change during long-time operation - same type modules can have different characteristics, when they have different work time. Therefore, values obtained from database will not be appropriate to gain maximum output power [1,2].

\section{Direct algorithms}

\subsection{P\&O - Perturb and Observe}

$\mathrm{P} \& \mathrm{O}$ method bases on causing module voltage to fluctuate and observing output power changes continuously. Voltage is increased or decreased in first 
step, and each next step depends on the output power change type. When it increases, voltage modification is continued, but if output power decreases, voltage is changed in opposite direction. (Fig. 6).

This method is very simple to use and cheap to implement. The only flaw is that oscillations are introduced into the system, therefore exact maximum power point cannot be reached, only its proximity. Also, voltage, current and output power measurements need to be done continuously. This method is not optimal, when insolation level changes rapidly. [2, 3].

One of the most important factors of MPPT algorithm rating is time to get to optimal operating conditions. Appropriate approach to decrease regulation time seems to be increasing voltage change value. This will unfortunately also increase output power fluctuations, which will affect whole system efficiency in negative way.

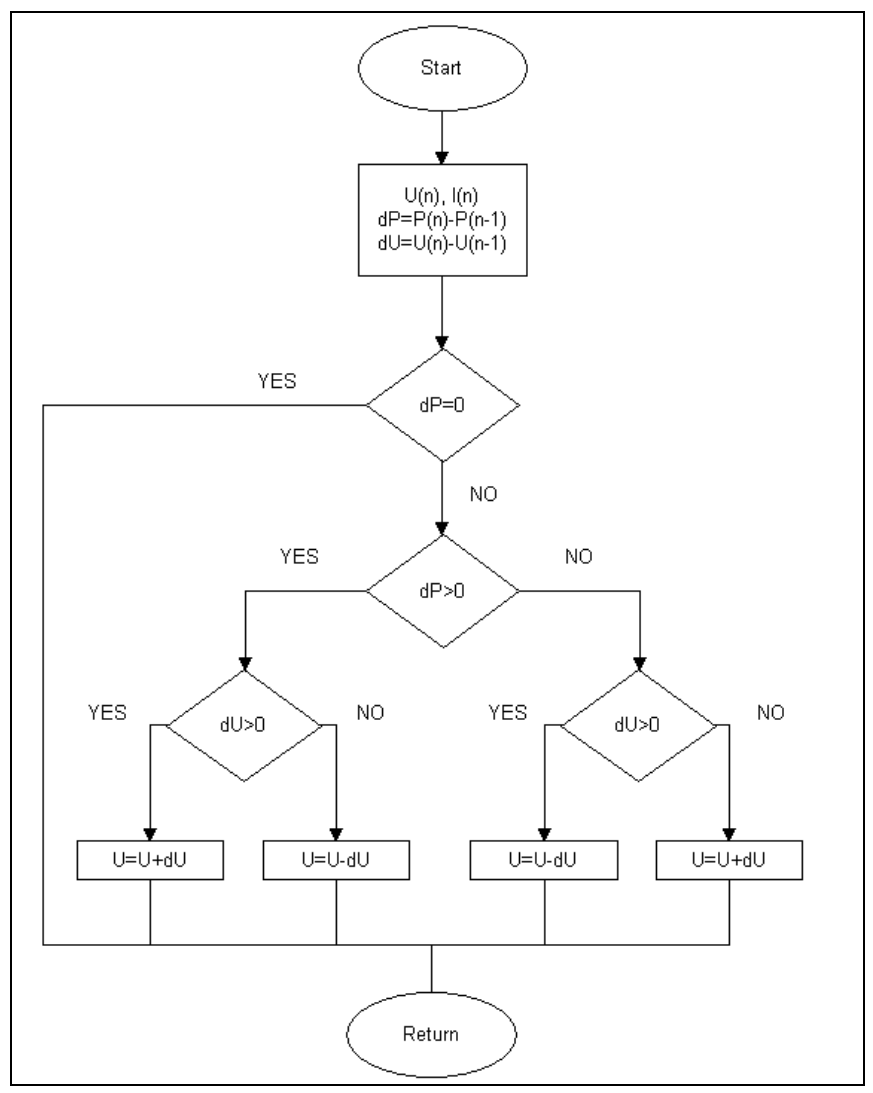

Fig. 6. P\&O algorithm details 
To partially circumvent the problem, variable voltage change value is used, basing on fuzzy logic. In this approach, voltage, current and output power changes values are used as input parameters. These parameters get their fuzziness by assigning them to fuzzy sets in appropriate degree of membership, using prepared functions. Obtained information is subjected to inference basing on implemented rule database, final degree of membership is calculated, which, after sharpening process, indicates the direction and value of next referential parameter change (for example voltage). This process is illustrated on figure 7.

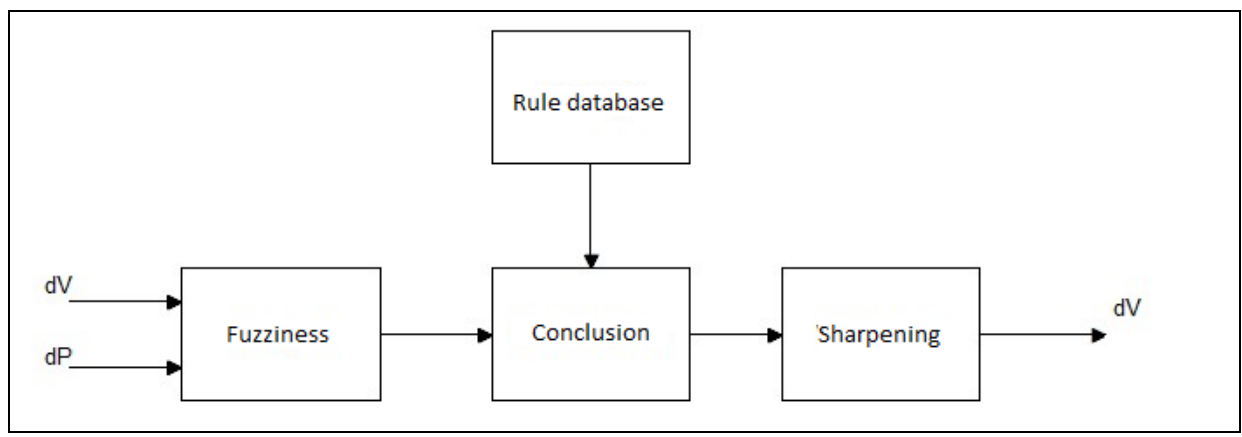

Fig. 7. Block diagram of the fuzzy logic MPPT algorithm

There are many other ways to make use of fuzzy logic in P\&O method. It allows to speed up algorithm speed and better approximation of maximum power point location. Adoption of fuzzy logic for this purpose allows to speedup algorithm and to achieve better approximation of maximum power point. Thanks to variable step value, which is not possible in conventional method, the closer to the MPP, algorithm can use smaller step value. In this case, oscillations will be much smaller in close MPP neighbourhood and whole system efficiency will increase as well. [4]

\subsection{Incremental conductance method}

This method bases on dependency (13).

$$
\frac{d P}{d U}=0
$$

It is true dependency when photovoltaic cell works in maximum power point. However, when the actual operating point is not the maximum power point, its location can be determined using the sign of derivative (14). 
a) $\frac{d P}{d U}>0 \quad$ b) $\frac{d P}{d U}<0$

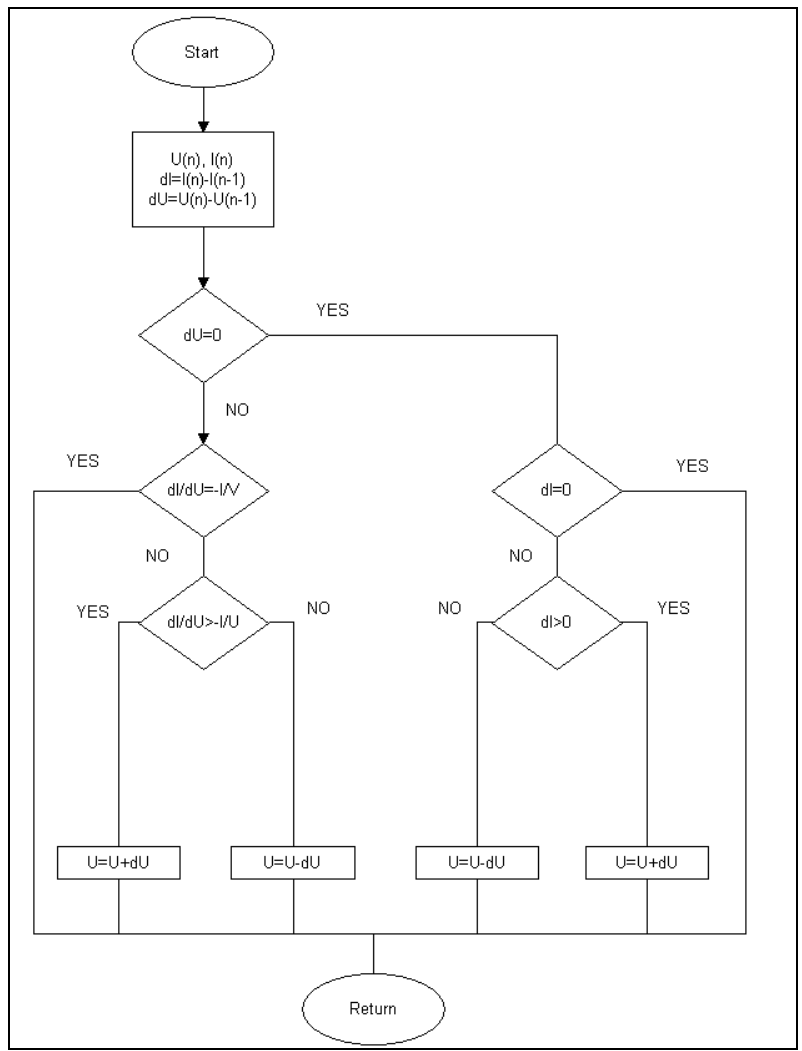

Fig. 8. Incremental Conductance algorithm on block diagram

When the dependency (14a) is true, it means that actual operating point is located on growing part of power characteristic and to achieve optimal operating point, voltage increasing is needed. In case when condition (14b) is true, the module is actually operating with voltage higher than $U_{M P P}$ - operating voltage has to be decreased to achieve MPP. Presented equations can be transformed as in (15).

$$
\frac{d P}{d U}=\frac{d(U I)}{d U}=I+U \frac{d I}{d U}
$$

Then, derivatives have to be replaced by increments. In the end, final dependencies are established, which are base for the method - (16). 

a) $\frac{\Delta I}{\Delta U}>\frac{I}{U}$
b) $\frac{\Delta I}{\Delta U}<\frac{I}{U}$

As in case (14), when (16a) is true, voltage has to be increased, but when equation (16b) is true, voltage has to be decreased to achieve maximum output power. Figure 8 presents the principles of this method.

Compared do $\mathrm{P} \& \mathrm{O}$ method, this algorithm can gain better efficiency for fast insolation fluctuations. What' more, oscillations near MPP for still atmospheric conditions as significantly smaller. As in $\mathrm{P} \& \mathrm{O}$, measurement of current and voltage is needed, which may be disadvantage of this method. However, the algorithm is continually improved - there is modification, which uses cell parasitic capacitance to calculate output. [5]

\subsection{Forced oscillations method}

In this method, small amplitude oscillations are introduced to reference value. Oscillation frequency can be about $100 \mathrm{~Hz}$. PV module output power changes in function of voltage are analysed and actual operating point is determined. In case when output power changes are in the same phase as voltage, actual operating point is located on the left of MPP. Therefore, reference value has to be increased. When signals are shifted relative to each other by $180^{\circ}$, actual operating point is located on the left of MPP - referential value has to be decreased. For maximum power point, oscillations have doubled frequency compared to modulated voltage. As a result of phase and amplitude analysis, maximum power point location is obtained - which allows to achieve variable step value and to model MPP more precisely. However, there are some problems in situations when low output power is generated by system. Oscillating and measuring part of the system is quite complicated to construct [6].

\section{Conclusion}

The article classifies and describes the most commonly used MPPT algorithms used in photovoltaics. Basing on their working principles, they were divided into direct, indirect and methods supported by artificial intelligence.

The most commonly used indirect methods include fractional method, "look-up table" and the curve fitting. However, due to much weaker possibility 
of approximating MPP, they are not used as a stand-alone algorithms. They can serve as a support for more efficient systems, eg. determining the approximate coordinates of the maximum power point.

The most commonly used direct algorithms are "perturb \& observe" and "incremental conductance". Their biggest problem is the introduction of oscillations in the power module output value. Therefore, these methods are constantly being improved and developed different modifications. Often they are supported by artificial intelligence (fuzzy logic, neural networks). This allows even better approximating the MPP and thereby increasing the efficiency of the system. Another example of algorithm of this type is a forced oscillation method.

Usage of MPPT algorithms in power electronics converter, which receives energy from photovoltaic modules allows to increase the amount power generated by PV power station. Thereby, financial benefits can be increased and payback time can be shortened. Algorithms mentioned are still being improved, therefore photovoltaic systems efficiency is growing.

\section{Reference list}

[1] Subudhi B., Pradhan R.: A Comparative Study on Maximum Power Point

Tracking Techniques for Photovoltaic Power Systems, IEEE transactions on Sustainable Energy, vol. 4, no. 1, January 2013, pp. 89-98.

[2] Zaremba A., Rodziewicz T., Wacławek M.: Algorytmy śledzenia punktu mocy maksymalnej (MPPT) w systemach fotowoltaicznych, Proceedings of ECOpole, 2012 DOI: 10.2429/proc.2012.6(2)112.

[3] Patil M., Deshpande.: Design and simulation of Perturb and Observe Maximum Power Point Tracking using MATLAB/Simulink, 2015 International Conference on Industrial Instrumentation and Control (ICIC) College of Engineering Pune, India. May 28-30, 2015, DOI: 10.1109/IIC.2015.7150957.

[4] Aashoor F. A. O., Robinson F. V. P.: A variable step size perturb and observe algorithm for photovoltaic maximum power point tracking, Universities Power Engineering Conference (UPEC), 2012 47th International, DOI: 10.1109/UPEC.2012.6398612.

[5] Shah K. B., Joshi L. P.: Comparative analysis of incremental conductance base MPPT for multi-string photovoltaic system, 2013 Nirma University International Conference on Engineering (NUiCONE), DOI: 10.1109/NUiCONE.2013.6780166.

[6] Tse K. K., Chung H. S. H., Hui S. Y. R., Ho M. T.: A novel maximum power point tracking technique for PV panels, Power Electronics Specialists Conference, 2001. PESC. 2001 IEEE 32nd Annual, 2001, vol. 4, pp. 1970-1975, DOI: $10.1109 /$ PESC.2001.954410 


\section{ALGORYTMY MPPT STOSOWANE W FOTOWOLTAICE}

\section{Streszczenie}

Ze względu na zmienność charakterystyki prądowo-napięciowej modułu fotowoltaicznego, algorytmy MPPT są ważnym elementem elektrowni fotowoltaicznej. Algorytm MPPT najczęściej steruje przekształtnikiem energoelektronicznym, który bezpośrednio odbiera moc z modułu lub grupy modułów. Punkt mocy maksymalnej zmienia swoje położenie, wraz ze zmianą nasłonecznia i temperatury pracy modułu. Istnieją metody pośrednie, bezpośrednie i wspomagane sztuczną inteligencją. Do metod pośrednich możemy zaliczyć m. in. metody ułamkowe i metodę look-up table, do bezpośrednich algorytm Perturb \& Observe oraz Incremental conductance. Szerzej stosuje się algorytmy bezpośrednie, gdyż lepiej odwzorowują punkt mocy maksymalnej od metod pośrednich, a wspomagane sztuczną inteligencją pozwalają jeszcze lepszym stopniu wyznaczyć optymalne warunki pracy. Stosowanie tych algorytmów pozwala zwiększyć efektywność produkcji energii, a tym samym korzyści finansowe po może znacząco skrócić czas zwrotu inwestycji. Są one w dalszym ciągu udoskonalane.

Słowa kluczowe: MPPT, fotowoltaika, zaburz i obserwuj, konduktancja przyrostowa, algorytmy bezpośrednie, algorytmy pośrednie

DOI: $10.7862 /$ re.2016.6

Tekst złożono $w$ redakcji: maj 2016

Przyjęto do druku: czerwiec 2016 